\title{
Problematika dalam Menghadapi Pembelajaran Work From Home pada Masa Pandemi Covid-19
}

\author{
Cici Handayani Rukmana, Masykur H. Mansyur, Abdul Kosim \\ 1,2,3 (Pendidikan Agama Islam, Universitas Singaperbangsa Karawang, Indonesia).
}

* Corresponding Author. E-mail: ${ }^{1}$ cicihandayani.chr@gmail

Receive: 13/05/2021

Accepted: 23/08/2021

Published: 01/10/2021

\begin{abstract}
ABSTRAK
Bekerja dari rumah (Work from Home/ WFH) adalah impian banyak orang saat ini, terutama bagi generasi milenial saat ini. Situasi global saat ini WHO telah mengumumkan pandemi global virus COVID-19 semakin membuat beberapa kebijakan di seluruh negara untuk mengarahkan pegawai swasta dan pegawai sipil untuk melakukan WFH. Penelitian ini bertujuan untuk menganalisis Problematika dalam menghadapi pembelajaran Work from Home pada masa pandemic COVID-19. Metode penelitian yang digunakan adalah metode kualitatif. Pengumpulan dengan dilakukan melalui literature review dari data yang dipublikasikan seperti artikel online, jurnal nasional maupun internasional yang diterbitkan pada tahun 2020-2021. Subyek penelitian ini adalah pegawai yang melakukan kerja dari rumah (WFH). Hasil penelitian menunjukkan beberapa kekurangankekurangan dari WFH yakni sarana prasarana terbatas, biaya tambahan, motivasi kerja menurun, dan adanya gangguan-gangguan selama bekerja WFH. Berdasarkan penelitian ini menujukkan bahwa penyebaran COVID-19 tentunya tidak hanya berdampak pada aspek kesehatan, tetapi juga secara umum berdampak pada aspek ekonomi, sosial, budaya, politik dan keamanan seluruh negara di dunia. Selain itu, adanya problematika dari WFH yang mempengaruhi sisi psikologis para karyawan. Untuk belajar dari situasi ini, semua organisasi harus memiliki strategi dan kapasitas untuk menghadapi perubahan yang terjadi dan tidak dapat diprediksi.
\end{abstract}

Kata kunci: Problematika, Working From Home, COVID-19

\begin{abstract}
Working from home / WFH is a dream for many individuals today, especially the millennial generation. Given the current global situation in which WHO has declared a global pandemic of the COVID-19 virus, numerous rules have been implemented throughout the country to direct private employees and civil servants to carry out WFH. The aim of this research is to analyze the problematics related to Work from Home during the COVID-19 pandemic. The research method used is s qualitative method. Data obtained through a literature review of published data such as online articles, national and international journals published in 2020-2021. The subjects of this research are employees who work from home. The study's findings revealed various drawbacks of WFH, including limited infrastructure, additional costs, diminished job motivation, and disruptions during WFH. Based on this research, it is undeniable that the spread of COVID-19 has an impact not only on health, but also on the economic, social, cultural, political, and security elements of all countries throughout the world. WFH also has problems that affect employees' psychological well-being. All organizations must have a strategy and capacity to deal with changing and unanticipated changes in order to learn from this circumstance.
\end{abstract}

Keywords: Problematics, Working From Home, COVID-19

\section{Pendahuluan}

Akses internet dan peningkatan infrastruktur teknologi informatika membuat WFH menjadi tren yang tidak bisa ditampik selama beberapa dekade terakhir. Bekerja dari rumah (Working from Home/ WFH) adalah impian banyak orang saat ini, terutama bagi generasi milenial saat ini, tidak perlu bangun pagi lalu mandi dan bersiap-siap untuk berlama-lama di kantor pulang dan bekerja. Situasi global saat ini WHO telah mengumumkan pandemi global virus COVID-19 semakin membuat beberapa kebijakan di seluruh negara untuk mengarahkan pegawai swasta dan pegawai sipil untuk melakukan WFH (Purwanto, 2020).

Sebelum pandemi, gagasan WFH adalah fantasi bagi banyak orang, tetapi praktik seperti itu 
dianggap tidak praktis untuk kota-kota padat penduduk. Hal ini terutama karena bekerja di rumah membutuhkan ruang yang tenang dan berdedikasi untuk melakukan tugas-tugas pekerjaan, yang dapat menjadi tantangan nyata bagi mereka yang tinggal di rumah mungil. Selama bertahun-tahun, ada kepercayaan di seluruh kota bahwa pekerja harus hadir secara fisik di kantor untuk melaksanakan pekerjaan. Sekarang pandemi telah memaksa uji coba WFH di kota, bagi banyak orang, ini adalah pertama kalinya mereka bekerja dari jarak jauh dan sebagian besar terbukti berhasil. Oleh karena itu, peluang unik untuk menilai kemungkinan menjadikan WFH sebagai salah satu model kerja masa depan untuk kota padat penduduk tersebut memiliki dampak yang tinggi (Vyas \& Butakhieo, 2021).

WFH memiliki efek menguntungkan bagi pengusaha dan karyawan. Keuntungannya, termasuk dan tidak terbatas pada pengurangan waktu perjalanan, menghindari politik kantor, menggunakan lebih sedikit ruang kantor, meningkatkan motivasi, meningkatkan keragaman gender (misalnya wanita dan karier), tenaga kerja yang lebih sehat dengan tingkat ketidakhadiran dan pergantian yang lebih sedikit, retensi bakat yang lebih tinggi, kepuasan kerja, dan produktivitas yang lebih baik (Mello, 2007). Beberapa penelitian menunjukkan bahwa kerja jarak jauh dapat mengurangi tingkat pergantian dan meningkatkan produktivitas, keterlibatan kerja, dan kinerja karyawan (Collins \& Moschler, 2009).

Literatur menunjukkan bahwa orang yang bekerja dari rumah membutuhkan fleksibilitas untuk alasan yang berbeda. Bekerja di rumah adalah solusi khas bagi mereka yang perlu mengasuh anak yang menjadi tanggungan tetapi banyak karyawan hanya mencari kehidupan kerja yang lebih baik bagi keseimbangan hidup dan kenyamanan lingkungan kerja alternatif. Beberapa literatur melaporkan manfaat efisiensi kerja untuk WFH tetapi juga menunjukkan beberapa kelemahan dari pengaturan ini. Contoh yang baik adalah eksperimen skala luas di mana karyawan call center secara acak ditugaskan untuk bekerja dari rumah atau di kantor selama sembilan bulan. Peningkatan kinerja kerja sebesar 13\% ditemukan pada kelompok kerja dari rumah. Para pekerja ini juga melaporkan peningkatan kepuasan kerja. Namun, setelah eksperimen, $50 \%$ dari mereka lebih suka kembali ke kantor terutama karena merasa terisolasi di rumah (AczelID, Kovacs, Lippe, \& Szaszi, 2021).

Oleh karena itu, kesempatan unik untuk menilai kemungkinan menjadikan WFH sebagai salah satu model kerja masa depan memiliki dampak yang tinggi. Menjadi salah satu studi pertama di bidang ini, peneliti bertujuan untuk menganalisis pemahaman tentang $\mathrm{WFH}$, termasuk faktor-faktor yang mempengaruhi problematika WFH dan kepraktisan dan efektivitas pengaturan kerja ini terhadap krisis COVID-19.

\section{Metode}

Penelitian ini menggunakan pendekatan kualitatif yang digunakan untuk mendapatkan informasi terkait dengan problematika konsep bekerja dari rumah (work from home) selama masa pandemi Covid-19. Metode penelitian ini yaitu deskriptif analitik yang merupakan metode untuk mendapatkan data yang mendalam, suatu data yang mengandung makna dan secara signifikan dapat mempengaruhi substansi penelitian (Sugiyono, 2018). Metode pengumpulan dengan dilakukan melalui literature review dari data yang dipublikasikan seperti artikel online, jurnal nasional maupun internasional yang diterbitkan pada tahun 2020-2021. Subyek penelitian ini adalah pegawai yang melakukan kerja dari rumah (WFH). Analisis data dilakukan dengan mereduksi data, penyajian data, dan diakhiri dengan penarikan kesimpulan.

\section{Hasil dan Pembahasan}

Hasil penelitian ini berisi informasi terkait dengan definisi Working From Home (WFH) dan Problematika dalam pelaksanaan WFH di masa pandemi COVID 19 berdasarkan hasil kajian literature dari beberapa artikel ilmiah terkait.

\section{Definisi Working From Home (WFH)}

Munculnya pandemi COVID-19 telah memaksa jutaan pekerja untuk mengalihkan aktivitas mereka dari kantor dan ke rumah mereka (Teodorovicz, Sadun, Kun, \& Shaer, 2021). Bekerja dari rumah (Working From Home) didefinisikan sebagai setiap pekerjaan berbayar yang dilakukan terutama dari rumah dan diperkirakan terdiri dari setidaknya 20 jam seminggu (Crosbie \& Moore, 2004). Pembuat kebijakan dan manajer umumnya memiliki minat yang tinggi terhadap WFH (Felstead \& Jewson, 2000) Faktor-faktor yang mempengaruhi WFH adalah keterampilan dalam manajemen waktu, kemungkinan bekerja pada jam-jam paling produktif, pengurangan waktu untuk berkomunikasi dengan rekan kerja, kemungkinan bekerja dari rumah ketika tidak sehat, kepercayaan dari atasan, dukungan dari atasan, kemungkinan menabung pada biaya transportasi, kemungkinan merawat anggota keluarga, kesesuaian tempat kerja di rumah, dan kemungkinan mengakses dokumen organisasi dari rumah. Agar kegiatan kerja dapat 
berjalan dengan baik, WFH membutuhkan beberapa bentuk dukungan.

Hasil survei terhadap lebih dari 369 orang dewasa di 64 kota di China menunjukkan bahwa $27 \%$ dari mereka bekerja di kantor, 38\% lebih suka bekerja dari rumah, dan $25 \%$ lebih memilih berhenti dari pekerjaannya karena pandemi. Salah satu pendukung utama adalah ketersediaan TIK, baik hardware maupun software serta edukasi terkait cara penerapan WFH itu sendiri. Selain itu, pelatihan yang diberikan dengan tepat pada akhirnya akan meningkatkan keterampilan karyawan. Sangat penting untuk mengatasi tantangan yang ada dan yang sedang berlangsung bagi karyawan yang terkena dampak pandemi COVID-19 (Hasan, Rehman, \& Zhang, 2021).

Sebuah studi baru-baru ini yang dilakukan terhadap 40 pekerja berpendidikan yang dipaksa bekerja dari rumah selama COVID menemukan bukti beberapa manfaat produktivitas dari WFH, tetapi juga beberapa kekhawatiran seputar efektivitas jangka panjang, kreativitas, dan ketahanan pribadi (Birkinshaw, Cohen, \& Stach, 2020) Bukti dari sampel besar email dan metadata rapat menunjukkan peningkatan tajam dalam rapat virtual dan email setelah penguncian yang diberlakukan pemerintah selama COVID (yang secara efektif memaksa WFH pada sampel besar pekerja), mungkin sebagai cara untuk mengkompensasi hilangnya interaksi fisik (DeFilippis et al, 2020).

Selanjutnya, hasil survei Jobstreet menunjukkan bahwa 46\% pekerja di Indonesia telah diwajibkan bekerja dari rumah (Work From Home/WFH) akibat pandemi virus corona Covid-19. Dari jumlah tersebut, $50 \%$ responden merasa durasi bekerja lebih panjang selama berada di rumah.

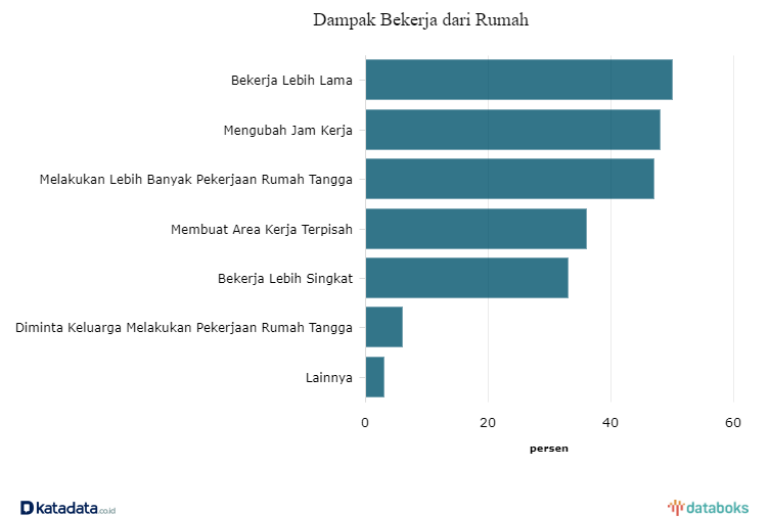

Gambar 1. Dampak Bekerja dari Rumah Sumber : (Databoks, 2020)

Problematika WFH Saat Pandemi COVID-19
Pertama, Berdasarkan hasil penelitian Rachmawati et al (2021), sebanyak 95\% responden menggunakan laptop dan ponsel sebagai perangkat keras untuk mendukung WFH. Hanya 5\% yang menggunakan PC, tablet, dan telepon rumah. Permasalahan yang muncul yaitu adanya perbedaan kualitas perangkat keras mempengaruhi kinerja karyawan karena respon yang lambat, pemanasan yang cepat, dan lain-lain. Faktor-faktor tersebut dapat menjadi kendala dalam pekerjaan karena tidak dapat dilakukan secara optimal. Selain itu, beberapa responden merasa WFH membuat mereka kehilangan fokus pada apa yang mereka lakukan karena koneksi internet yang lambat dan fasilitas yang tidak memadai. Setidaknya 60\% responden menyatakan setuju, koneksi internet bisa menjadi kendala dan tidak bisa fokus bekerja selama WFH.

Kedua, menurut penelitian dalam Jurnal Satyagraha yang berjudul Studi Eksplorasi Dampak Work From Home Pada Kinerja Karyawan BUMN Di Wilayah Denpasar Karyawan Di Masa Pandemi Covid-19 yang diteliti oleh Salain et al (2021), menunjukkan bahwa Konsep bekerja dari rumah memiliki kelemahan dari segi biaya. Biaya yang menjadi kendala adalah kenaikan biaya penggunaan internet untuk setiap keluarga, walaupun mendapatkan kompensasi dari kantor, namun hal ini masih menjadi kendala utama, karena kecepatan internet harus disesuaikan dengan letak geografis rumah masing-masing pegawai. Selain itu, meskipun memberikan waktu yang fleksibel untuk menyelesaikan pekerjaan, jika waktunya terlalu lama akan menyebabkan kurangnya motivasi untuk bekerja. Hal ini dikarenakan pekerjaan yang diselesaikan sesuai dengan waktu kerja normal dapat tertunda. Selanjutnya, sebagai wanita yang sudah menikah, terkadang pekerjaan rumah menjadi prioritas utama saat berada di rumah, terutama bagi wanita yang sudah menikah.

Ketiga, berdasarkan hasil kajian Ma'rifah (2020), masih banyak karyawan yang kesulitan menerapkan sistem WFH yang diberlakukan secara mendadak. Hal ini disebabkan oleh berbagai alasan, baik yang berhubungan dengan pekerjaan maupun yang berhubungan dengan individu karyawan. Beberapa bentuk pekerjaan, misalnya, masih mengandalkan berkas fisik dan peralatan kantor, yang mengharuskan karyawan datang ke kantor untuk memenuhi tugas. Jika individu diharuskan untuk bekerja dari rumah, ia mungkin tidak dapat melakukannya.

Keempat, Mustajab et al (2020) menemukan bahwa Semangat kerja karyawan menurun akibat kesalahpahaman bahwa rumah adalah tempat untuk beristirahat, bukan tempat untuk bekerja. Hal 
ini menyebabkan karyawan kehilangan fokus saat memutuskan untuk bekerja atau menghabiskan waktu bersama keluarga selama masa karantina pandemi Covid-19. Penurunan semangat kerja juga dapat disebabkan oleh berbagai gangguan di rumah, seperti ajakan untuk ngobrol dengan keluarga, mengobrol dengan teman, atau memantau media sosial, serta godaan untuk bersenang-senang, seperti menonton TV, bermain dengan anak-anak, atau melakukan sesuatu yang menjadi hobi, yang kesemuanya berakibat pada keterlambatan pekerjaan. Hal ini juga dapat disebabkan karena tidak terlihat batasan jelas antara kantor dan rumah, bahkan cenderung waktu kerja menjadi tanpa batasan.

Kelima, Menurut penelitian Chung et al (2020) dalam Jurnal University of Kent, ada beberapa pengalaman negatif bekerja di rumah selama lockdown. Sebanyak 2/3 karyawan mengidentifikasi batasan kabur antara pekerjaan/rumah sebagai aspek negatif utama dari bekerja dari rumah. Banyak yang mencatat kurangnya peralatan dan ruang untuk bekerja saat bekerja dari rumah. Hilangnya interaksi dengan rekan kerja dicatat sebagai aspek negatif utama dari bekerja dari rumah, terutama di kalangan wanita tanpa anak. Kelompok ini juga lebih cenderung merasa gugup dan stres selama lockdown daripada rekan-rekan pria mereka.

\section{PEMBAHASAN}

\begin{abstract}
Munculnya
memaksa jutan pandemi COVID-19 telah mekerja untuk merelokas aktivitasnya dari kantor ke rumah (Teodorovicz, Sadun, Kun, dan Shaer, 2021). Para pembuat kebijakan dan manajer pada umumnya memiliki minat yang besar terhadap WFH (Felstead \& Jewishson, 2000). Faktor-faktor yang mempengaruhi WFH antara lain adanya keterampilan manajemen waktu, kemampuan untuk bekerja pada jam yang paling produktif, pengurangan waktu yang dihabiskan untuk berkomunikasi dengan rekan kerja, kemampuan untuk bekerja. dari rumah jika terjadi ketidaknyamanan, kepercayaan atasan, dukungan atasan, kemampuan menghemat biaya transportasi, kemampuan merawat anggota keluarga, kesesuaian kantor pusat, dan kemampuan mengakses arsip organisasi dari rumah. Namun di sisi lain, WFH juga memiliki problematika berdasarkan beberapa penelitian yang dibahas diatas maka peneliti mengklasifikasikan kekurangan-kekuranga dari WFH:
\end{abstract}

\section{Sarana prasarana terbatas}

Fenomena WFH sebagai upaya pencegahan COVID-19 di belahan dunia secara umum memberikan beberapa keuntungan dan kerugian, namun yang paling sering dirasakan oleh karyawan (berdasarkan hasil penelitian) adalah keterbatasan saranan dan prasarana yang dimiliki oleh karyawan. Penelitian dari (Rachmawati et al, 2021) menunjukkan bahwa Hanya 5\% yang menggunakan PC, tablet dan telepon rumah. Selain itu ada permasalahan pada perbedaan kualitas perangkat keras yang mempengaruhi kinerja karyawan melalui respon yang lambat, pemanasan yang cepat dan lain-lain. Keterbatasan komunikasi seringkali disebabkan oleh masalah teknis seperti gangguan jaringan internet sehingga mereka kesulitan dalam mengirimkan data dan informasi pekerjaan satu sama lain. Hal ini juga ditambah dengan penelitian kedua yang ditulis oleh (Salain, Adiyadnya, \& Rismawan, STUDI EKSPLORASI DAMPAK WORK FROM HOME PADA KINERJA KARYAWAN BUMN DI WILAYAH DENPASAR KARYAWAN DI MASA PANDEMI COVID-19, 2021), bahwa kendala lain karena kecepatan internet harus disesuaikan dengan letak geografis rumah masing-masing pegawai.

\section{Biaya tambahan}

Namun, dengan melakukan WFH, akan ada tambahan pembiayaan. Untuk masalah ini, penelitian-penelitian diatas menunjukkan para informan menyatakan bahwa dengan melakukan WFH banyak tagihan yang mereka keluarkan seperti kenaikan listrik, internet, dan biaya komunikasi, berbeda ketika mereka bekerja di kantor, semua pembiayaannya tentunya ditanggung oleh pemberi kerja, karena menggunakan perangkat elektronik, pengiriman data dan pembuatan virtual komunikasi lebih sering mengakibatkan lonjakan tagihan yang harus mereka bayar dan masalah ini membebani pengeluaran rutin mereka.

\section{Motivasi kerja menurun}

Karyawan yang melaksanakan WFH merasakan penurunan motivasi kerja, hal ini disebabkan oleh situasi dilematis dan mentalitas yang dimiliki "menganggap rumah sebagai tempat istirahat". Namun, saat bekerja dari rumah, berdasarkan penelitia-penelitian diatas menjelaskan para informan (pegawai-pegawai WFH) merasakan kehilangan fokus bekerja selama bersama keluarga. Selain itu penelitian menunjukkan bahwa mereka mengalami kurangya bersantai menikmati masa karantina wilayah dan social distancing untuk mencegah penyebaran COVID19. Penelitian dari (Mustajab et al, 2020) menjelaskan bahwa penurunan motivasi kerja juga disebabkan oleh banyak gangguan, seperti ajakan untuk berkomunikasi melalui jejaring sosial, 
interaksi sosial dengan rekan kerja tanpa membicarakan pekerjaan, dan menikmati pilihan hiburan yang tersedia seperti menonton film, karaoke dan bermain dengan teman secara langsung membuat putus asa. Para pegawai hanya melakukan pekerjaan yang ditugaskan dan mengaku semangat kerja berkurang sehingga mereka sering menunda pekerjaan mereka.

Selain itu penelitian dari (Chung, Seo, Forbes, \& Birkett, 2020) menjelaskan bahwa hilangnya interaksi dengan rekan kerja dicatat sebagai aspek negatif utama dari bekerja dari rumah, terutama di kalangan wanita tanpa anak. Kelompok ini juga lebih cenderung merasa gugup dan stres selama lockdown daripada rekan-rekan pria mereka. Hal ini menjelaskan bahwa mereka merasakan perbedaan dari aspek psikologis dimana sebelum wabah COVID-19, mereka selalu berinteraksi di lingkungan kerja. kantor dan berkomunikasi secara langsung sehingga mereka dapat melihat wajah dan tanggapan orang lain secara langsung.

\section{Gangguan}

Selama WFH, banyak karyawan yang merasakan gangguan teknis lainnya sehingga sering kehilangan fokus dan memilih untuk menunda pekerjaan hingga menemukan kembali semangat kerja dan mengurangi gangguan untuk melakukan atau menyelesaikan pekerjaan. Hal ini ditunjukkan berdasarkan penelitian dari (Ma'rifah, 2020) bahwa beberapa bentuk pekerjaan, misalnya, masih mengandalkan berkas fisik dan peralatan kantor yang mengharuskan para pegawai harus datang ke kantor untuk memenuhi tugas. Jika individu diharuskan untuk bekerja dari rumah, ia mungkin tidak dapat melakukannya. Pekerjaan dengan teknis yang berubah dan kebiasaan yang berbeda ini tentu bisa menjadi gangguan tersendiri bagi para pegawai.

\section{Analisis Problematika Work From Home pada Masa Pandemi COVID-19}

Penyebaran COVID-19 tentunya tidak hanya berdampak pada aspek kesehatan, tetapi juga secara umum berdampak pada aspek ekonomi, sosial, budaya, politik dan keamanan seluruh negara di dunia. Untuk belajar dari situasi ini, semua organisasi harus memiliki strategi dan kapasitas untuk menghadapi perubahan yang terjadi dan tidak dapat diprediksi. COVID19 telah mengubah budaya organisasi dan juga produktivitas sumber daya manusianya, WFH kini menjadi fenomena di berbagai negara dan memberikan kontribusi nyata bagi organisasi melalui dampak positif dan negatifnya. Meski sudah banyak karyawan yang merasakan manfaat dari
WFH, namun pasti ada risiko dan kerugian yang perlu diwaspadai karena muncul kelelahan yang dapat menurunkan motivasi kerja melalui multitasking dimana banyak karyawan harus mengerjakan dua pekerjaan sekaligus, seperti pekerjaan rumah dan kantor.

Akibat dari penjelasan di atas, karyawan WFH sering kehilangan konsentrasi dalam bekerja, hal ini disebabkan banyaknya distraksi dari tugas-tugas sekunder yang menyebabkan gangguan memori pada tugas utama mereka, terutama pada karyawan yang telah cukup usia lanjut. Namun penggunaan media kerja seperti notebook, laptop dan alat komunikasi yang juga harus digunakan terkadang mempengaruhi produktivitas kerja karyawan ketika informasi dan komunikasi ini harus diterima baik dari atasan maupun karyawan. Hal ini menunjukkan problematika dari WFH juga mempengaruhi sisi psikologis para karyawan (Jacobs, 2017). Sehingga hal ini perlu menjadi perhatian khusus oleh para organisasi baik swasta dan pemerintah terhadap sisi psikologis para karyawan karena produktivitas dan motivasi kerja sangat mempengaruhi terhadap output organisasi tempat para karyawan juga bekerja.

\section{Simpulan}

Munculnya pandemi COVID-19 telah memaksa jutaan pekerja untuk mengalihkan aktivitas mereka dari kantor dan ke rumah para pekerja. Adanya fenomena baru yakni dengan adanya bekerja dari rumah ini (Working from Home/ WFH) memberikan problematika tersendiri. Hal ini ditemukan dari penelitian-penelitian yang telah peneliti kaji. Peneliti menemukan bahwa beberapa kekurangan-kekurangan dari WFH yakni sarana prasarana terbatas, biaya tambahan, motivasi kerja menurun, dan adanya gangguangangguan selama bekerja WFH. Berdasarkan penelitian ini menujukkan bahwa penyebaran COVID-19 tentunya tidak hanya berdampak pada aspek kesehatan, tetapi juga secara umum berdampak pada aspek ekonomi, sosial, budaya, politik dan keamanan seluruh negara di dunia. Hal lain juga adanya problematika dari WFH yang mempengaruhi sisi psikologis para karyawa. Untuk belajar dari situasi ini, semua organisasi harus memiliki strategi dan kapasitas untuk menghadapi perubahan yang terjadi dan tidak dapat diprediksi.

\section{Daftar Pustaka}

AczelID, B., Kovacs, M., Lippe, T. v., \& Szaszi, B. (2021). Researchers working from home: Benefits and challenges. Plos One Journal, 2. 
Birkinshaw, J., Cohen, J., \& Stach, P. (2020). Knowledge Workers Are More Productive from Home. Productive from Home.

Chung, H., Seo, H., Forbes, S., \& Birkett, H. (2020). Working From Home during the COVID-19 Lockdown: Changing Preference and Future of Work. Journal of the University of Kent (KAR).

Collins, J. H., \& Moschler, J. J. (2009). he Benefits and Limitations of Telecommuting. Defense AR Journal 16 (1).

Crosbie, T., \& Moore, J. (2004). Work-Life Balance and Working from Home. Soc. Policy Amp.Soc, 223-233.

Databoks. (2020, Agustus). Mayoritas Karyawan Anggap WFH Buat Durasi Kerja Lebih Lama. Retrieved from https://databoks.katadata.co.id/datapublis h/2020/11/05/mayoritas-karyawananggap-wfh-buat-durasi-kerja-lebih-lama\#

DeFilippis et al. (2020). Collaborating during Coronavirus: the impact of COVID-19 on the Nature of Work. Cambridge,MA.

Felstead, A., \& Jewson, N. I. (2000). In Work, At HomeTowards an Understanding of Homeworking. New York: Routledge.

Hasan, S., Rehman, A., \& Zhang, W. (2021). Who Can Work and Study from Home in Pakistan: Evidence from a 2018-2019 Nationwide Household Survey. World Dev.

Jacobs, R. L. (2017). Knowledge Work and Human Resource Development. Human Resource Development Review, 16(2).

Ma'rifah, D. (2020). IMPLEMENTASI WORK FROM HOME:KAJIAN TENTANG DAMPAK POSITIF, DAMPAK NEGATIF DAN PRODUKTIVITAS PEGAWAI. Civil Service, 14(2), 53-63.

Ma'rifah, D. (2020). Implementasi Work From Home:Kajian Tentang Dampak Positif, Dampak Negatif Dan Produktivitas Pegawai. Civil Service, 14(2), 53-63.

Mello, J. A. (2007). Managing Telework Programs Effectively. Employee Responsibilities and Rights Journal 19 (4).

Mustajab et al. (2020). Working from Home Phenomenon as an Effort to Prevent COVID-
19 Attacks and Its Impacts on Work Productivity. The International Journal of Applied Business, 4(1), 13-21.

Purwanto, A. (2020). Studi Eksplorasi Dampak Work From Home(WFH) Terhadap Kinerja Guru Selama Pandemi Covid-19. EduPsyCouns Journal, Vol. 2, No. 1, 93.

Rachmawati et al. (2021). Work from Home and the Use of ICT during the COVID-19 Pandemic in Indonesia and Its Impact on Cities in the Future. Sustainability, 13(6760), 1-17.

Salain, P. P., Adiyadnya, M. S., \& Rismawan, P. A. (2021). STUDI EKSPLORASI DAMPAK WORK FROM HOME PADA KINERJA KARYAWAN BUMN DI WILAYAH DENPASAR KARYAWAN DI MASA PANDEMI COVID-19. Jurnal Satyagraha, 3(2), 19-27.

Salain, P. P., Adiyadnya, M. S., \& Rismawan, P. A. (2021). Studi Eksplorasi Dampak Work From Home Pada Kinerja Karyawan BUMN Di Wilayah Denpasar Karyawan Di Masa Pandemi COVID-19. Jurnal Satyagraha, 3(2), 19-27.

Sugiyono. (2018). Metode Penelitian Kuantitatif, Kualitatif, dan R\&D. Bandung: Alfabeta.

Teodorovicz, T., Sadun, R., Kun, A. L., \& Shaer, 0. (2021). Working from Home during COVID19: Evidence from Time-Use Studies. Harvard Business School Working Paper, 154.

Vyas, L., \& Butakhieo, N. (2021). The impact of working from home during COVID-19 on work and life domains: an exploratory study on Hong Kong. Policy Design and Practice, 4:1.

\section{Profil Penulis}

Cici Handayani Rukmana. Lahir Garut, 06 Juni 1999. Mahasiswa S1 Fakultas Agama Islam, Prodi Pendidikan Agama Isalm Universitas Singaperbangsa Karawang. Jl. HS. Ronggo Waluyo, Paseurjaya, Kec. Telukjambe Timur Kabupaten Karawang, Jawa Barat 41361 